\title{
Responsabilidad del Estado \\ El Estado: Sus poderes y roles y el ambito de su actuación
}

\author{
Jorge Mosset Iturraspe
}

"Pocos juristas nos han impresionado tanto como el Profesor do Couto e Silva. Ocurre que unía a su particular sapiencia una simpatía y entusiasmo que lo distinguía de los demás. Era capaz de pronunciar sin leer conferencias en varios idiomas a cual mas atracvista y erudita. La Argentina lo contó entre sus amigos dilectos. Nos visitó en ocasión de distintas Jomadas y Congresos. Su oratoria atraía y cautivaba al auditorio. A su lado nos sentíamos 'amigos de toda la vida'. Era un jurista universa, de aquellos que pueden encontrarse en las Universidades de Alemania o de Francia. Pero era, por sobre todas las cosas, un latinoamericano, amante de su Brasil y muy en especial de su Porto Alegre natal. Con él conversamos temas de Obligaciones $y$ de Contratos. Las novedades en materia de responsabilidad por daños y podemos afirmar que estaba al corriente de las 'iltimas ideas', de los mas recientes avances de la Ciencia Jurídica. La muerte lo sorprendió cuando aún esperabamos mucho de él, y lo encontró en lo suyo, cumpliendo tareas académicas. Do Couto e Silva fue un gran Profesor, un Maestro de generaciones y un amigo entrañable."

\section{CAPÍTULO INTRODUCTÓRIO:}

1. ¿Qué significa hablar de la "responsabilidad del Estado"?

2. Responsabilidad por daños causados por el Estado. La visión publicista.

3. Daños originados en el actuar de la Administración Pública.

Daños nacidos del obrar del Poder Judicial.

Daños provenientes de las normas emanadas del Poder Legislativo.

4. Los hechos dañosos del Estado Nacional.

Del Estado Provincial y 


\section{Del Estado Municipal.}

5. Las esferas o ámbitos de actuación de la Administración Pública:

- los hechos ilícitos;

- los actos y contratos;

- los hechos ilícitos que originan daños injustos.

1.1. Si responder es dar respuesta sobre los propios actos, acerca de su razón de ser o rendir cuentas, aparece clara la gravedad de la cuestión, respecto del Estado.

1.2. Semejante actitud se compadece con los Estados Democráticos de Derechoy no es imaginable en los Estados autoritarios o despóticos.

1.3. A esta conclusión nos lleva una visión histórica sobre el tema: en la Antiguedad, en el Medioevo e incluso em la Modernidad; hasta la aparición de los Estados sujetos al Derecho, no se concebía semejante responsabilidad. La voluntad del Príncipe era soberana. Las tres etapas.

2.1. La responsabilidad por daños protege a la víctima de un daño injusto, causado por el Estado. Sea un particular, una persona jurídica o un funcionario. Inconvenientes de las normas civiles.

2.2. La responsabilidad por daños es diferente, entonces, de otras responsabilidades en las que el Estado puede incurrir: moral, social, política, administrativa. Los adeptos de la Constitución Nacional.

2.3. La responsabilidad internacional del Estado. El incumplimiento de Pactos o Tratados Internacionales.

3.1. Nuestro tema, el de este tomo, será el de la responsabilidad de la Administración Pública. Veremos si tienen vigencia distingos como el de los "actos iure imperii", opuestos a los "iure gestionis". Las Constituciones Provinciales.

3.2. La responsabilidad por el "error judicial" ha sido el tema del tomo 8 de esta obra. Alli dijimos lo suficiente.

3.3. Sobre la responsabilidad de "los legisladores" por las leyes inconstitucionales o inicuas, dijimos, lo poco que puede decirse, en el tomo 3, p.480.

4.1. ¿Un Estado, com actuación em esferas distintas, o varios Estados, com responsabilidad diferentes?

4.2. De la unidad del Código Civil a la diversidad del Derecho Administrativo.

4.3. iLa pluralidad de "responsabilidades", sujetas a regulaciones locales, tiene ventajas o inconvenientes?

5.1. ¿Es predicable, respecto de la responsabilidad del Estado, la superación del distingo entre los ámbitos contractual y extracontractual o aquiliano?

5.2. De los "privilegios" en la aplicación del "naeminem laedere" a los "privilegios" 
en los actos o contratos que celebra la Administración. La fundamentación de la responsabilidad.

5.3. iEs imprescindible que la Administración se coloque em situación dominante o de superioridad em la contratación administrativa?

\section{CAPÍTULO INTRODUCTORIO:}

1.1. ¿Cómo debemos visualizar al Estado dañador? Como a uma persona cualquiera o como a una "privilegiada", merecedora de especial consideración $y$, por ende, con particular benignidad?

Desconocer que el enfoque del tema nos ha de enfrentar necesariamente con principios y normas de un Derecho que busca afirmar su autonomía, el Derecho Administrativo, es harto peligroso y nos expone a "construir" marginando la realidad.

Pero habiendo aceptado que el Derecho de la Responsabilidad del Estado no es materia del Derecho Civil, caen dos interrogaciones liminares:

- Cuánta ingerencia le cabe al Derecho Administrativo; y,

- Cuál es el Derecho Administrativo del cual hablamos.

Auque toda calificación o rotulación es riesgosa nos atrevemos a distinguir:

a) Un Derecho Administrativo "autoritario" que pone el acento en el "poder"o "imperio" de sus órganos, como depositarios de la soberanía, o outro D. A. que podemos llamar "democrático", convencido de la necesidad de ajustar su actuación al Estado de Derecho y de Justicia, ciñéndose a la Constituición y a las leyes, a la vez que a la palabra empeñada, preocupado por la defensa de los Administrados;

b) Un Derecho Administrativo que otorga especial relevancia al "poder de Policia" - tema central en orden a los daños causados por actos lícitos o por actos ilícitos, en ejercicio o con ocasión de las funciones encomendadas - u outro D.A. que prescinde del Poder de Policia como "noción fundante del sistema"; para partir delos derechos de los individuos, las personas humanas, "que son la base del sistema democrático de gobierno".' Este segundo D.A., que sostenemos, rechaza "un derecho administrativo al sevicio de la autoridad y del poder, como "poder de policia";

c) Un Derecho Administrativo que consagra un modelo absolutista del acto administrativo, a favor del funcionario o agente público y en contra del particular a quien afecta; "in dubio pro administratione" y no "in favorem libertatis". Un D.A. partidario de la "zona de reserva", de las "facultades implícitas", de la discrecionalidad, etc. Preferimos un ordenamiento en el cual eje del sistema de control, el centro de análisis, son las

\footnotetext{
Gordillo, A., Tratado de Derecho Administrativo, t.2. 4ta. Edic., edic. Fundación de Derecho Administrativo, Bs. As. 2000, p. V-1 y ss.
} 
pretensiones procesales del individuo y no el acto administrativo impugnado. La pretención procesal com objeto del proceso; ${ }^{2}$

d) Un Derecho Administrativos que ha edificado toda una teoría del "contrato administrativo" a partir de las cláusulas exorbitantes, de las facultades de la Administración para apartarse del mismo, modificarlo o extinguilo; desde una relación vertical o de dominio; seguridad a los cocontratantes; que explicita las cláusulas que estima relevantes para los intereses públicos, sobre la base de una relación horizontal o de cordinación. ${ }^{3}$

Por ahora, y como introducción, nos parecen suficientes estas referencias. Nos permiten anticipar que las diferencias acerca de una "Responsabilidad Pública del Estado", ampliadas o extendidas - magnificadas - por "administrativistas de la Administración" se recortan o reducen cuando el diálogo se plantea con "administrativistas de los Administrados". 4

El cuestionamiento a estas ideas, que ya han dejado de ser novedosas, para tener aceptación en la doctrina autoral y judicial, en particular en otras latitudes ${ }^{5}$, desde la visión del Derecho de Daños, puede incluir una o varias de las proposiciones siguientes:

- i un Estado ampliamente responsable no es un Estado débil o vulnerable?

- i no da pié o incentiva las pretensiones infundadas de las pseudo víctimas?

- la Administración ha menestar de "herramientas fuertes" en su propia defensa;

- que es la tutela del bien común, del interés general, del bienestar de la comunidad;

- los recursos del Estado son insuficientes para hacer frente a los "gastos" que insumen las indemnizaciones por daños contractuales y extracontractuales;

- de ahí que la Responsabilidad Pública, a diferencia de la privada o civil, deba ser limitada y de ninguna manera plena o integral;

- el Estado no puede montar un aparato jurídico defensivo que esté a la altura del que disponen los privados en su contra;

- de donde, las "ventajas" o posibilidades defensivas que le otorga el Derecho Administrativo vienen a ser un especie de compensación frente a esas diferencias;

- la multiplicación de las condenas resarcitórias deteriora la imagen del Estado;

- la ciudadanía confunde el error de los funcionarios con el error del Estado y de ahí que las equivocaciones deban interpretarse testrictivamente.

\footnotetext{
2 Parrino, P.E., Las pretensiones procesales en el nuevo Código Contencioso Administrativo bonarense", en E.D. 180-878 y ss.

${ }^{3}$ Mairal, H. La teoría del contrato administrativo, en Contratos Administrativos, Editorial Ciencias de la Administración, obra colectiva, p.209 y ss., Bs.As. 2000.

${ }^{4}$ Mosset Iturraspe, J., La teoría general de la responsabilidad civil y el Derecho Administrativo, en La Responsabilidad, homenaje a I. Goldenberg. Edic. Abeledo-Perrot. Bs.As. 1995, p.763 y ss.

${ }^{5}$ García de Enterría, E., Revolución francesa y Administración contemporánea, Madrid 1981; del mismo autor: La lucha contra las inmunidades del poder en el Derecho Adminisirativo, Madrid 1979. Mairal, H.A., Responsabilidad del Estado en el Derecho Comparado, en Responsabilidad del Estado y del Funcionario Público, edición Ciencias de la Administración, obra colectiva, p.367 y ss., Es.As. 2001.
} 
La síntesis y la conclusión son QUE LA RESPONSABILIDAD PÚBLICA DEL ESTADO, CON BASE EN EL DERECHO ADMINISTRATIVO, ES DIFERENTE A LA PRIVADA DEL CODIGO CIVIL EN CUANTO RECEPCIONA CUESTIONES ESPECÍFICAS DEL ESTADO QUE SE CONCRETAN EN UNA EVIDENTE ATENUACIÓN DE SU RESPONSABILIDAD COMO CAUSANTES DE DAÑOS INJUSTOS. ${ }^{6}$

1.2. Es innegable que en tema de "responsabilidad del Estado" se ha avanzado y mucho. Hemos partido de la irresponsabilidad o no responsabilidad para arribar a una situación en la que se debate si debe ser plena o limitada; comprender todos los daños en relación causal adecuada o ciertos daños, dejando afuera los extrapatrimoniales y el lucro cesante; si la contractual es la misma del Código Civil o admite diferencias y, en su caso, cuáles son éstas, etc.

Se va abriendo consenso en el sentido que el Estado moderno, de una República democrática e igualitaria, debe distinguirse del Estado borbónico o napoleónico. Buscando vías de mayor justicia y seguridad, protegiendo al ciudadano en todos sus roles, incluso como consumidor y usuario.

La fama, el prestigio, la eficiencia del Estado no se logra hoy con la impunidad; con la protección a todo viento de los malos funcionarios y agentes. Por ese camino sólo se coadyuva a la corrupción.?

No se cae en la cuenta que la protección al Estado, declarando la irresponsabilidad, es también la proteción a los malos agentes o funcionarios, cuyo obrar fue la causa del perjuicio. Y, a la inversa, que la admisión del error del Estado es la aceptación de la equivocación del funcionatio actuante, cualquiera sea su jerarquía, como autor del un ilícito dañoso.

Mas de una vez, luego de haber leído o escuchado a un Profesor de Derecho, nos preguntamos sobre la incidencia, en su pensamiento jurídico de sus ideas políticas. Creemos que un "jurista monárquico", para dar un ejemplo, puede llegar a conclusiones muy diferentes a la de otro jurista, democrático e igualitario éste. Y si esta reflexión la hemos volcado en temas de "Daños", en general, con mucha mayor razón cuanto se trara de

\footnotetext{
${ }^{6}$ Un libro de Derecho, una investigación jurídica, no es una "novela", que reserva para el final el "descubrimiento de la trama". Nos parece bueno decir desde el inicio cual es nuestro pensamiento, por lo demás ya antecipado en otros trabajos. El desarollo apunta entonces a "sostener" y "mantener" los criterios postulados.

7 Es lo que pensamos de la decisión de la Corte Suprema de Justicia de la Nación, dictada con fecha 20 de Noviembre del 2001, en autos: "Recurso de hecho deducido por la defensa de Emir Fuad Yoma...", causa $n^{\circ} 798 / 95$, en cuanto, entre otras afirmaciones, sostine que "no resiste el análisis la imputación de falsedad ideológica a decretos del Poder Ejecutivo ni al Convenio realizado entre el Ejercito Argentino y la Dirección de Fabricaciones Militares. En efecto, no se comprende como pueden contituir la mencionada figura delictiva decretos del Presidente de la República, que son órdenes dictadas en el ejercicio de las atribuciones que le confiere la Constitución..."
} 
daños que se pretenden imputar al Estado y ser la base de una condena a indemnizar. De una condena que, para muchos, atenta contra el principio de la soberanía del Estado; de su existencia "sólo para hacer el bien"; de su obrar siempre, inspirado en el orden público, las buenas costumbres y el bienestar general.

De allí a la "idolatría del Estado" hay un paso. La justicia deja de ser "conmutativa", destinada a dat a cada uno lo suyo y, por tanto, al dañado una reparación, para ser "justicia distributiva", manejada por el Estado conforme a sus intereses. ${ }^{8}$

1.3. La historia de la responsabilidad del Estado es la historia de los fallos de la Corte Suprema de Justicia de la Nación.

Al conjuro de ésas decisiones se ha evolucionado. No siempre de manera lineal; según los tiempos políticos y económicos. ${ }^{9}$ Avanzando en un sentido "progresista" y humanitario, hacia una mayor responsabilidad, o retrocediendo, en aras del "autoritarismo" o de la preocupación "por la Caja o bolsa del Estado". 10

La doctrina nacional mayoritaria coincide en señalar "tres épocas" en el camino recorrido por la SC:

- una primera época que va desde la sanción del Código Civil hasta el 22 de setiembre de 1933, com el dictado por la CS de la sentencia en el caso "Devoto". Las figuras jurídicas descollantes son, en el campo "privatista", el Codificador, Vélez Sarsfield; y en el "publicista" Rafael Bielsa. Las tesis son simples:

1. se le reconoce al Estado una "doble personalidad", como "poder público" y como "persona jurídica";

2. se distingue entre los "actos de gestión" y los de "iure imperii";

3. el Estado es irresponsable por los actos de sus agentes como Poder Público, tal la función de la Policia - en autos "Wicky c/ Provincia de Entre Ríos"; salvo disposición legal expresa - causa "Brown, F. c/Estado Nacional", de 1919.

4. en cambio, el Estado responde en el ámbito contractual, por tratarse de actos "iure gestionis."

\footnotetext{
${ }^{8}$ Es el criterio sostenido por Ivonne Lambert Faivre, em la doctrina francesa, sobre la base de considerar que el "derecho de daños" ha ido demasiado lejos y que se ha de cambiar la condena individual del agente por un reparto social o fraccionamiento de la reparación.

"En lo "político" han incidido, sin lugar a dudas, las ideas autoritárias acerca del Estado y la subestimación de los "derechos humanos". Veremos luego que la culminación del segundo período puede razonablemente ubicarse en pleno Proceso Militar en 1980. En lo "económico" ha incidido el "endeudamiento crónico del Estado y su general estado de insolvencia".

${ }^{10} \mathrm{El}$ "retroceso" ocurre en vários frentes y no solo en los recortes a una reparación plena o integral a cargo del Estado. Acontece en el mantenimiento de "inmunidades", en la lucha por el levantamiento previo de la "cosa juzgada"; en la defensa de la actuación legislativa; en el requisito de un sumario administrativo, etc. Gordillo menciona: "...la ley 23.892 de consolidación de deudas del Estado; la negativa judicial a devolver el ahorro obligatorio, salvo del modo dispuesto por el mismo Congreso; en la declaración de constitucionalidad de la forzosa transformación de depósitos bancarios en bonos de la deuda pública a largo plazo..., etc." . Tratado, t.2, p.XX-6. En el mismo sentido Alterini, A.A., La inseguridad juridica, edic. AbeledoPerrot, Bs.As., 1993.
} 
5. se aplican las normas del Código Civil: el art. 43, que declara que las personas jurídicas no son responsables ni civil ni penalmente, y los arts. 1112 y 1113 que obligan a responder a los funcionarios y a los dependientes. ${ }^{11}$

Las palabras de Bielsa, que rechazaba la responsabilidad del Estado a falta de una norma expresa que la estableciera, son elocuentes e iluminadoras. Dice el distinguido administrativista comentando el fallo Devoto: "Este fallo que parece dictado en una causa entre particulares ${ }^{12}$ - pero que lo es en contra del Gobierno nacional, es decir, contra el Estado, poder público - aún cuando se presente como un caso común, tiene una significación jurídica insospechada. Implica, desde luego, la rectificación de una jurisprudencia que se levantaba contra la desidia legislativa, pues el legislador no ha sancionado sino excepcionalmente la responsabilidad del Estado. Por eso, aunque el fallo se funda en principios de derecho común, vale la pena examinarlo a través de la doctrina y de la legislación comparada, ya que, como decimos, la jurisprudencia de la Corte Suprema ha mantenido invariablemente el principio contrario al que ahora acaba de aplicar." ${ }^{3}$

- una segunda época, que va desde 1933 a 1980, aproximadamente ${ }^{14}$, caracterizada por un "aumento" de la responsabilidad del Estado; por la incorporación de la denominada "responsabilidad por los actos lícitos"15, con la aplicación básicamente de las normas del Código Civil, ahora reforzadas, en la materia, por la reforma de 1968- ley 17.711, al art. 43, consagrando la responsabilidad civil de las personas jurídicas dicas. Destacamos en este período la labor de los civilistas, en especial de Alberto Gaspar Spota, partidario firme de esta responsabilidad, con o sin norma expresa, y de Guille rmo Boer, "autor" de la reforma aludida. Son sus aspectos más relevantes:

\footnotetext{
"Los administrativistas, basicamente, han mantenido un debate acerca de los verdaderos alcances del art. 1112 , en relación mas que con su texto, que es claro para nosotros, con la fuente mencionada por el Codificador, la obra de Aubry y Rau, donde se señala que el Estado actúa como comitente de sus respectivos funcionarios y empleados; esto tiene que ver también con el debatido carácter "directo" o "indirecto" de la responsabilidad del Estado. Volveremos sobre estas cuestiones.

12 Ese es, para nosotros el ideal, la meta buscada: que el Estado sume su responsabilidad a la para de los privados, sin pretender "privilégios" ni "escudos protectores".

${ }^{13}$ La causa "Devoto" se encuentra en J.A. 43-416, con nota de Bielsa: Responsabilidad del Estado como Poder Administrador. Se trataba de la producción de un incendio por culpa de agentes del Estado, en oportunidad de reparar un telégrafo. Este "leading case" fue criticado por Bielsa, quien sostuvo que la responsabilidad debía recaer sobre el agente y no sobre la Administración. Destacan su importancia: Barraza, Actualidad en la Jurisprudencia sobre la responsabilidad extracontratual des Estado, en L.L. 2000 - A - 943; y Bianchi, A., Panorama actual de la responsabilidad del Estado en el Derecho Comparado, en L.L. 1996 - A - 922.

${ }^{14}$ Gordillo - ob.cit. - entiende que el tema comenzó a mostrar cambios importantes en la década del 90 ; creemos que es verdad, pero que los estudios doctrinarios que posibilitaron esas mutaciones datan de la década del 80 y, en especial, de la obra de Marienhoff.

${ }_{15}$ Dedicamos al tema un Capitulo especial. Antecipamos, el trabajo de Ghersi, C.A., Responsabilidad del Estado por actos lícitos o cumplidos en realización de políticas, en Responsabilidad del Estado, Revista de Derecho de Daños, t.9, edic. Rubinzal y Culzoni, Santa Fe, 2000, p.271 y ss.
} 
1) los distintos fallos que va dictando la Corte, comenzando, luego de Devoto, por la causa: "F.C.O. c/ Provincia de Buenos Aires", de 1938, donde aludió expresamente a los arts. 1112 y 1113 del Cod. Civil ${ }^{16}$; la causa "Etchegaray" de 1941, en la cual se aceptó la responsabilidad del Estado extracontratual, por la actividad ilícita de sus empleados en el desempeño de su función ${ }^{17}$; en "Rabanillo", ya en 1945 la Corte decidió que lo relevante era "el motivo de ejecución" y no meramente la "ocación" "; en 1978, y en "Cantón", después, en 197919, la Corte admite la "responsabilidad extracontractual del Estado por los daños ocasionados sin culpa a los particulares", con fundamento en los arts. 14 y 17 de la Constitución Nacional; empero, mientras en "Cípolini" se dijo que "la forma de hacer efectiva ésta garantía es necesario buscarla en los principios del Derecho Común...", en "Canton", por razones de "analogía", art. 16 del Cod. Civil, se dejaron de lados aquellas normas para atender a las de la "expropiación"20;

2) la consideración del Código Civil no sólo como subsidiario sino mas bien como "supletorio del derecho administrativo; rigiendo en todas aquellas situaciones no reguladas especialmente; por entender que no es posible "dejar al Estado fuera de los principios

${ }^{16}$ En "F.C.O." la Corte juzgó la responsabilidad de la Provincia de Buenos Aires por la expedición de un certificado de dominio falso. La condena se fundó en el denominado "servicio públíco irregular" y se aplicaron los arts. 1112 y 1113 del Codigo Civil, con base en la justicia y la equidad. El fallo se encuentra en J.A. 64-6 en L.L. 12-123, con nota de Spota, A.G., La responsabilidad aquiliana de la Administración Pública.

17 En "Ełchegaray" la Corte resolvió que el Estado era resonsable por la actividad ilícita de un agente que excedió sus funciones al pretender atrapar a un presunto delincuente, cuya conducta imprudente determinó "concurrencia de culpas"; en L.L. 24-821, connota de Bielsa: La responsabilidad del Estado y la responsabilidad de los funcionarios, en la cual discrepa con el fallo por entender que la responsabilidad "es directa y exclusiva" del agente. Gaidos, J.M., Responsabilidad extracontractual del Estado en la Corte Suprema de la Nación. Principales pautas directrices, en Revista de Derecho de Daños, ob. Cit. P.25 y ss.

18 "Rabanillo" trataba del homicidio de un portero de una Facultad Nacional asesinado por el mayordomo de la misma que, con un pretexto, to condujo al zótano donde lo mató. En L.L. 43893. El comentario de Galdos, en la relación de dependencia y la responsabilidad des Estado, en L.L. $1996-\mathrm{c}-557$.

19 "Cipolini" se encuentra en Fallos 300-143; se trataba de daños originados en "actos administrativos". "Cantón" se originó en un Decreto del Ejecutivo que prohibió la importación de un producto determinado. Se trataba de un contrato de compraventa internacional. La Corte dijo la Justicia no puede, en esta materia "revisar el acierto o el error" del Estado. Comentamos este fallo en L.L. 1979 - c - 219, Mosset Iturraspe, J., Indemnización de daños por el Estado. Sacrificio de derechos patrimoniales como consecuencia de actos lícitos.

${ }^{20}$ Es indudable que la Corte buscó fundar la responsabilidad del Estado en una institución del Derecho Público, como es la expropiación, abandonando las bases civilisticas. Es provechosa la consulta de Martín-Retortillo Baquer, S., El Derecho Civil en la génesis del Derecho Administrativo $y$ de sus instituciones, edic. Civitas, Madrid 1996; en esta obra, muy aplicable a nuestro tema, se destacan los esfuerzos en Francia y en España por "ganar la batalla de la autonomía del Derecho Administrativo". La confrontación viene desde antiguo, ya en 1831 escribía Tocqueville: "...el derecho administrativo y el derecho civil forman como dos mundos separados, que no viven siempre en paz, pero que no son ni muy amigos ni muy enemigos... Yo he vivido en uno de ellos, ignorando lo que pasa en el otro". 
jurídicos". De este modo se mantiene una responsabilidad "unitaria" o "única" para los ámbitos públicos y privado, el Estado y los particulares; ${ }^{21}$

3) se juzgan a las normas del Código Civil como "derecho común" y se predica que es la propia Constitución Nacional la que declara al Código Civil ley básica de la Nación y "si la Carta Magna nada dice acerca de la responsabilidad estatal esté asunto se debe regir por las leyes a las de la reforma - 1112, 1113, 1109 del Código Civil tengan vigencia frente al Estado dañador;

4) con base en la Constitución Nacional se reconoce la responsabilidad del Estado por actos lícitos que quiebren el principio de igualdad ante las cargas públicas o impongan sacrificios a algunas personas;

5) el fin de la etapa lo marca, desde nuestra óptica y sin pejuicio de otros criterios que también juzgados válidos ${ }^{22}$ - y con la salvedad acerca de la índole imprecisa de todo período o etapa que refiera a la evolución jurídica, la sentencia en la causa "Cantón", de 1979, al dejar de lado "el derecho común" - el Código Civil - para recurrir a una "ley administrativa" como es la de expropiación.

- una tercera etapa, por al cual aún transitamos, en la que se evidencia la puja o confrontación entre los criterios de la responsabilidad civil, sostenida como "unica" para todas las personas, incluído el Estado - persona jurídica pública y necesaria - y los propios del derecho administrativo, "que es pronuncia por la total independencia de los principios del Código Civil que regulan la responsabilidad estatal"23 y busca en aquel derecho las soluciones específicas. En esta etapa - que, reiteramos, es la que aún nos toca vivir, sin una definición a favor de una o otra solución - sobresale, en el derecho administrativo, la predica de Miguel Marienhoff, a partir de su Tratado de Derecho Administrativo, y en el campo privatista las "recomendaciones" de Congresos y Jornadas ${ }^{24}$

\footnotetext{
${ }^{21}$ Es la conclusión a la que arriba Kemelmajer de Carlucci-A. $\mathrm{R}$, La responsabilidad del Estado enfoque jurídico privado, en Responsabilidad del Estado, obra colectiva, edic. UNSTA, Tucumán 1982, p.55 y ss. - : "Hemos pretendido demonstrar como - pese a las grandes diferenclas que median entre la posición que asume el Estado y la que afrontan los particulares - existen principios comunes, que no pueden ni deben ser olvidados ni por administrativistas ni por privatistas. Quizás ha llegado la hora de hablar de un "derecho de la responsabilidad" que reúna todos los principios generales, sin perjucion de los especificos para cada orden normativo."

22 Gordillo - ob. cit., t.2, XX-5 entiende que el cambio se empieza a operar en la década del 90, con el fenómeno de la privatización, "transferencia masiva de funciones o cometidos del Estado hacia particulares"; agrega que "esa traslación va acompañada de una mutación temporal, aunque sustancial, tanto formal como informal como informal de la responsabilidad clásica del Estado".

${ }^{23}$ Vázquez, R.A., Responsabilidad aquiliana del Estado y sus funcionarios, edic. La Ley, Bs.As. 2001,2 da. Edic. p.462. En el mismo sentido buena parte de la doctrina administrativa actual. Es la tesis defendeida por Reiriz, quien afirma que la "regulación de las cuestiones de Derecho Administrativo es local", en Responsabilidad del Estado, en El Derecho Administrativo hoy, edit. Ciencias de la Administración, Bs.As. 1996.

${ }^{24}$ Entre los encuentos mas destacados sobre la responsabilidad que nos ocupa señalamos: las Terceras Jornadas Sanjuaninas de Derecho Civil, celebradas en San Juan en 1986; las Jornadas Chaqueñas de Derecho Civil y Procesal Civil, de 1987, Comisión n³; y el II Congreso Internacional de Derecho de Daños, celebrado en Buenos Aires, en 1991; en éste último, la Comisión n³, sobre "Ubicación de la responsabilidad del Estado en el Derecho de daños", recomendó: "La responsabilidad del Estado constituye en capítulo en el campo del Derecho de daños, sin perjuicio de sus aspectos particulares".
} 
y los textos legales incorporados a los Proyectos de reforma al Código Civil de $1993^{25}$ y de $1998^{26}$. Son sus aspectos mas relevantes:

1) Una especie de diálogo de sordos; cada uno mantiene su postura y parece ignorar la del adversario. Administrativistas y civilistas "sesionan por separada", debaten y extraen conclusiones en Jornadas y Congresos. Es así como el Proyexto del 93, luego de reiterar el art. 1112 delCódigo vigente, agrega: "sin que sea necesaria su previo desafuero-el del funcionario - ni la determinación de su responsabilidad administrativa". Y el del 98, además de reiterar en términos semejante esta soluciónn, art.1677, agrega que: "...el Estado responde por los daños causados por el ejercicio irregular de la actividad de sus funcionarios o empleados, mediante acciones u omisiones, sin que sea necesario identificar al autor"; ${ }^{27}$

2) Los Administrativistas no le van en zaga; se apoyan en las especificidades de la actuación del Estado, tanto en el ejercicio del denominado Poder de Policia como en lo atingente a sus "actos" y "contratos" administrativos; recurren, como vimos, a la Justicia Distributiva y a las soluciones de la ley de expropiación por causa de utilidad pública y pretenden, en síntesis, construir una "responsabilidad propia", distinta, del Derecho Público, independizada del Código Civil, a la "medida de las necesidades del Estado"; ${ }^{28}$

3) El destino de tales esfuerzos, de uno y de otro, es aún incierto; asistimos a la paradoja de una responsabilidad interna del Estado "atenuada" y de otra, "externa", ampliada..$^{29}$ De un Estado que se ha reducido, con la "privatización" y la "desregulación", pero aún así no puede "controlar" la actuazión de sus funcionarios. De un Estado insolvente que procura no pagar sus daños. De un Estado que quiere conmatir la corrupción pero, a la vez, mantener imunidades o escudos protectores para sus agentes y funcionarios. ${ }^{30}$

${ }^{25}$ Artículos 1581 y 1582 que ratifican la voluntad de mantener una reponsabilidad única. Integraban la Comisión redactora de éste Proyecto: Belluscio Bergel, Kemelmajer de Carlucci, Le pera, Rivera, Videla Escalada y Zannoni.

${ }^{26}$ Artículos 1675,1676 y 1677. Integravab la Comisión redactora de éste Proyecto: Alegria, Alterini, A.A., Alterni, J.H., Méndez Costa, Rivera y Roitman.

${ }^{27}$ Ambos proyectos como la doctrina civilista de esta época, concluyen en la responsabilidad concurrente o indistinta o solidaria imperfecta, del funcionario y del Estado, a quien la víctima puede demandar a su elección, a uno de ellos o a ambos.

aB Marienhoff, a quien hemos señalado como "jefe de fila" del movimiento separatista ha escrito que "un sistema de Derecho Administrativo no es completo sino cuando el ciudadano tiene el medio de obtener una reparación de los perjuicios que le ocasiona el Estado" - en su Tratado, 6 ta. edic. actualizada 1997, I.IV, p. 718. Empero esta responsabilidad se visualiza desde la optiva del Derecho Público. $Y$ no solamente desde el Derecho Constitucional, - aludido por la Corte Suprema en la causa "Santa Coloma": "...la sentencia apelada lesiona el principio alterum non laedere, que tiene raiz constitucional (art. 19 de la Ley Fundamental) y ofende el sentido de justicia de la sociedad, cuya vigencia debe ser afianzada por el Tribunal, dentro del marzo de sus atribuciones y en concordancia con lo consagrado en el Preámbulo de la Carta Magna" - sino también del Derecho Administrativo.

${ }^{29}$ Gordillo, ob.cit. t.2, p.XX-4, con cita de los casos "Giroldi", de 1995, en L.L. 1995-D - 462, y Arce, de 1997, en L.L. 1997-F, 696. Es también el cado de las "inversioness extranjeras", con cláusulas de responsabilidad internacional que genera también supuestos de responsabilidad interna.

${ }^{30}$ Las variadas "limitaciones" a la responsabilidad del Estado, que se van construyendo en el Derecho Administrativo son, a la postre, beneficiosas para los funcionarios, y no solo para el Estado. 
2.1. No es frecuente encontrar autores del Derecho Público que, a la hora de ocuparse de la responsabilidad del Estado, comiencen por señalar "los inconvenientes que se derivan de utilizar normas civiles para resolver una cuestión propia del Derecho Público". Esta tarea ha sido cumplida por Horacio Rosatti, especialista en Derecho Público Provincial, y vamos a recordarle a continuación. Es obvio que no la compartimos, pero nos parece enriquecedor transcribir sus expresiones. Rosatti comienza señalando que "más allá de haber permitido dar solución a casos concretos, el trasvasamiento jurídico plantea serios inconvenientes: ${ }^{31}$

a) Se desvirtúa la lógica de los problemas y de sus posibles soluciones, al sujetarlos a un enfoque diferente: aquel que parte del perjuicio sufrido por el particular y no del objetivo perseguido por la actividad estatal; 32

b) Se genera una fuente adicional de incertidumbre jurídica, por cuan to no existe unanimidad - ni nada que se le parezca - directamente, por reenvío o en subsidio - y cuales no son aplicables a los temas de Derecho Público concernidos; ${ }^{33}$

c) Como tercera inconveniente, menciona Rosatti que "en el mejor de los casos, cuando se "encuentra" la norma civil para resolver una cuestión propia del Derecho Público - por analogía, aplicación subsidiaria o reenvío - tal preocupación queda enmarcada dentro del "Derecoh común" y no del "Derecho federal", con las disvaliosas consecuendias que en materia de "derecho a la jurisdicción" - de abolengo constittucional - produce este encuadramiento"; 34

\footnotetext{
${ }^{31}$ Rosatti, H., La responsabilidad extracontractual del Estado en base a las normas del Código Civil: una crítica, en Responsabilidad del Estado, en Revista de Derechos de Daños, no9, ob.cit. p.73 y ss. ${ }^{32}$ Outra vez el debata sobre la primacia, en el tema, de la "justicia conmulativa, que manda restiuir lo suyo al perjudicado por la privación de algún bien de su titularidad, o la justicia distributiva, "que regula relaciones entre el todo (la comunidad, actuando como órgano de ella la autoridad) con la parte, esto es los ciudadanos...Tal distribución puede estar ordenada al bien común, pero tambien puede ser ordenada directamente al bien de los individuos miembros de la comunidad". Soto Kloss, E., La responsabilidad pública: un enfoque politico (Un retorno a la idea clásica de restitución), en Responsabilidad del Estado, ob.cit. edic. UNSTA, p.17 y ss. Para este importante administrativista chileno debe, en materia de responsabilidad del Estado, estarse a la idea clásica de "restitución" a la víctima de la integridad perdida, sin que la justicia distributiva sea un obstáculo para ello.

${ }^{33}$ Las ideas de supletoridad o subsidiariedad - lo supletorio suple o reemplaza una falta; 10 subsidizio es aquello que concurre robustese o socorre a lo principal - en esta matéria, vienen del Derecho Administrativo y son, muchas veces, repetidas por los privatistas sin caer en la cuenta de su transcendência. Para los civilistas la responsabilidad del Estado "se encuentra en el Código Civil" y las normas del Derecho Administrativo la complementan o integran; pero no es la inversa; de donde no cabe hablar ni de una inexistencia de normas ni de una regulación "principal" fuera del Código Civil.

${ }^{34}$ El Código Civil es una ley de la Nación, la $n^{2} 340$, como son también leyes de la Nación las que se mencionan por Perrino - P.E., La responsabilidad de la Administración por su actividad ilicita (Responsabilidad por falta de servicio), en E.D. 185-781 y ss. - a quien Rosatti cita, para fundar el distingo entre el "derecho común" y el "derecho federal". Sostiene que son "uederales" las leyes; 19.501, modificada por la 22.511, que establece el régimen resarcitorio para el personal de las Fuerzas Armadas; la 16.973 que establece un subsidio par a los parientes de integrantes de la Policia Federal fallecidos en cumplimiento del deber; la 24.203 sobre reparación a personas privadas de la libertad durante la vigencia del estado de sitio en los años del Processo; la 21.499 sobre expropiación por causa de utilidad pública, etc. En cambio no sería federal el art. 1112 del Código Civil ni los restentes textos del mismo cuerpo. Empero, agregamos nosotros, si el tema se "traslada" a las Provincias, por no ser el derecho administrativo cuestión delegada, tampoco encuadra en el denomindado "derecho federal".
} 
d) Finalmente, afirma el autor que transcribimos, - y esta consecuencia no es menor - al retacearle contenido propio se desjerarquiza el Derecho Público. Desde el punto de vista científico, este desplazamiento retrasa el progreso de uno de los pilares sobre los que debe afirmarse la estructura de un sistema jurídico democrático. En efecto, la contribución del Derecho al logro del bien común se vertebra con la búsqueda del dinámico equilibrio entre los principios de libertad y de autoridad. ${ }^{35}$

Pensamos que los argumentos expuestos, que como anticipamos no compartimos, son insuficientes y parten de una visión limitada, parcial o conflictiva de la responsabilidad en el Derecho Privado. Se desconocen los desarollos que esa responsabilidad ha producido en los últimos treinta años que llevan, por vía de ejemplos, a resarcir los daños que encuentran una causa de justificación, borrando la antijuridicidad, pero que, desde la mirada de la víctima resultan "injustos"; así como también frente a las "omisiones" tiende a imponerse un criterio que pone el acento en la contrariedad con el Derecho y no meramente con la legalidad. ${ }^{36}$

La búsqueda de la "uninimidad" no es posible en temas de Derecho, pero si es dable hallar tendencias fuertes, criterios que se van imponiendo en la doctrina.

No creemos que se jerarquice el Derecho Público con la construcción de "otra responsabilidad", diferente a la de las personas jurídicas posible; que apunta, con el pretexto de atender al "bien común", a suavizat o atenuar las consecuencias del obrar dañoso del Estado; recortando la indemnización que la víctima merece, dejando ciertos perjuicios cubrir. Una indemnización "parcial" no es una indemnización "justa", puesto que mantiene a la víctima desprotegida y le obliga a soportar, pese a su incocencia, parte del detrimentos a menocabo.

2.2. ¿ Si se abandona el Código Civil a qué normas se recurre? ¿ Cuáles serían las bases del denominado "sistema normativo específico" de una responsabilidad del Derecho Público?

Rosatti, autor que seguimos en esta materia" ${ }^{37}$ afirma que "son preceptos constitucionaless fundantes de la responsabilidad del Estado, entre otros:

- El deber de "afianzar la Justicia", y la invocación de Dios como "fuente de toda razón y justicia", en el Preámbulo.

\footnotetext{
${ }_{35}$ Libertad, autoridad y justicia, diríamos nosotros. Es lo que se extrae del Estado de Derecho, tantas veces citado - incluso por Marienhff - como base de la responsabilidad del Estado.

${ }^{36}$ Ambos temas aparece tratados en el tomo Primero de ésta obra; en la p.90, nos ocupamos de la "responsabilidad sin antijuridicidad", como paso previo a la responsabilidad del Estado "por el obrar lícito"; y en la p. 64 nos referimos a la "omisión antijurídica", al comentar el art. 1074 del Cod. Civil.

37 Rosatti, ob.cit. p.88 y ss:; menciona como opiniones coincidentes con su visión de la responsabilidad pública del Estado, las Linares, J.F., Fundamentos de Derecho Administrativo, edic. Astrea, Bs.As. 1975; Escola, J., Compendio de Derecho Administrativo, edic. Depalma, Bs.As. 1990.
} 
- La adopción de la forma republicana de gobierno (arts. 1, 29, 33 y concds.) que debe ser asumida igualmente por las Provincias (arts. 5 y 6 ).

- El principio de "igualdad ante la ley" y su proyección, la "igualdad ante las cargas públicas", (art.16).

- El derecho de propiedad y su carácter inviolable (art. 17).

- La defensa en juicio como requisito inexorable previo a la aplicación de una pena (art.18).

- La intervención de los magistrados en caso de perjucio a terceros (art. 19 a contrario sensu).

- La concepción del derecho positivo como un siste ma jerárquico con vértice en la Constitución 'arts. 28, 31 y conds.' cuyo imperio se mantiene aún en el caso de golpe institucional (art. 36).

- La "ética pública" como principio rector de la función pública (art. 36).

- La participación ciudadana en los organismos de control de los servicios públicos (art. 42).

- La reparación judicial sumaria ante actos u omisiones de autoridades públicas, que lesionen, restrinjan, alteren o amenacen derechos y garantías reconocidos por la Constitución, un Tratado o una ley (art. 43).

- El principio de justicia social (arts. 75, inc. 19).

- La igualdad real de oportunidades (art. 75, inc. 23).

- El control de la administración pública (art. 86).

- La demandabilidad judicial del Estado (art. 116).

- La judiciabilidad para la protección del principio de legalidad y de los intereses generales de la sociedad (art. 120)."

Un lector inadvertido podría sorprenderse ante la absoluta ausencia en la Constitución Nacional de referencias a la responsabilidad del Estaclo, no obstante la alusión, ya recordada, al "neminem laedere", art. 19.

Nos parece que puede extraerse de ése silencio una conformidad con la regulación civilística; la consideración acerca de que el tema está ya tratado allí, sin necesidad de agregaciones o aditamentos. No se trata solo de la Constitución del 53 sino de las reformas posteriores, en especial de la de 1994.

No podemos perder de vista que en otros países, como en la República Federativa del Brasil, la Constituición de 1988, en su artículo 37, apartado 6to., declara que: "Las personas jurídicas de Derecho Público y las de Derecho Privado prestadoras de servicios públicos, responderán por los daños que sus agentes, en esa calidad, cauaren a terceros, asegurando el derecho de regreso contra el resonsable en los casos de dolo o culpa". Y el Código Civil del Brasil, a partir de la reforma del 2001, expresa en su art.43: "Las personas jurídicas de Derecho Público interno son civilmente responsables por los actos de sus agentes que en esa calidad cause daños a terceros, reservándose el derecho de regreso contra los causantes del daño si hubiere, por parte de éstos, culpa o dolo". 
Equivale a sostener que la Constitución y el Código Civil concurren a construir la responsabilidade del Estado, en situación de fuerte paridad con las personas jurídicas privadas. $^{38}$

2.3. Hemos señalado ya, con cita de Gordillo, que mientras en los últimos tiempos - seguramente en la década del 90 - la responsabilidad interna del Estado tiende a atenuarse, por muy variadas vías o caminos, la denominada "responsabilidad externa del Estado", con base en Tratados Internacionales, tiene a "aumentar"o expandirse. ${ }^{39}$ También se alude, con insistencia a una "responsabilidad del Estado en el Derecho de Integración", a partir de lo que está ocuriendo en la Comunidad Europea y de las decisiones del Tribunal de Justicia de dicha Comunidad. ${ }^{40}$

Un capítulo importante de esta responsabilidad internacional del Estado lo coonstituye la denominada "violacióna los derechos humanos", desprendida de la Convención Americana de Derechos Humanos, que posibilita canalizar los reclamos sobre indemnizaciones ante la Corte Interamericana de Derechos Humanos de Washington. ${ }^{41}$ Obviamente esta Convención tiene, entre nosotros, jerarquía constitucional, y las demandas, sorteada las etapas de conciliación y acuerdos amistosos, pueden concluiren condenas contra el Estado Nacional. ${ }^{42}$

Otra clara fuente de responsabilidad internacional del Estado constituyen los convenios internacionales de "protecciónn de Inversiones estranjeras". Gordillo afirma que son mas de cuarenta los tratados bilatarales en esta materia. Es cada vez mas frecuente la búsqueda de tribunales extranjeros y la tendencia - superada la idea de la "rebeldía", de nos comparecer ni aceptar la jurisdición - es a llegar a un acuerdo sobre el pago de lo reclamado, para evitar las sanciones - como la del aumento del "riesgo País", por las calificadoras privadas internacionales, y con ello que se eleve la tasa de interés flotante que el país debe por todas sus deudas externas. ${ }^{43}$

Finalmente, los contratos de otorgamiento de créidito externo, celebrados en le extranjero, sometidos a la jurisdición extranjera, cobrados allí y acompañados de una

${ }_{38} \mathrm{Y}$ no obstante ser un pais federal, como el nuestro, no se les ocurre editicar una responsabilidad del Estado a nivel "local", estadual o de cada porvincia.

${ }^{39}$ Gordillo, A., Responsabilidad del Estado en el Derecho Internacional, en Responsabilidad del Estado y de Funcionario Público, ob.cit. p.361 y ss.

${ }^{40}$ Barra, R.C., Responsabilidad del Estado en el Derecho de Integración, en Responsabilidad del Estado..., ob.cit. nota precedente, p.373 y ss., con cita de fallos del Tribunal de Justicia de la Comunidad Europea.

41 Martins, D.H., Los tratados Internacionales como fuente del Derecho Administrativo, en la obra colectiva Homenaje al Dr. Miguel S. Marienhoff, edic. Abeledo-Perrot, Bs.As. 1998.

${ }^{42}$ Se recuendan los casos: "Birt", comentado por Gordillo en L.L. 1995- D - 292; también la causa: "Verbitscky c/ Belluscio", comentada por el primero en su libro: Un mundo sin periodistas, Bs.As, edic. Planeta 1997, entre otras.

${ }^{43}$ Gordillo, ob.cit. p.364. Es muy dura y a la vez ilustrativa la frase que este jurista dedica a los abogados que defienden en el extranjero los intereses nacionales: "...la defensa...es altamente deficitaria: los abogados del Estado no tienen instrucciones en cuanto a cómo llebar el fondo del asunto, y por ello, utilizan principal o exclusivamente defensas formales. Si éstas caen el Estado ha quedado indefenso." 
renuncia expresa a todo tipo de defensas o excepciones. Es, sin lugar a dudas, una muestra de la "globalización" y de la consecuente pérdida de soberanía de los Estados periféricos. ${ }^{44}$

La experiencia acerca de la responsabilidad del Estado en el derecho de integración es rica en la Comunidad Europea; ${ }^{45}$ no ocurre lo mismo en el Mercosur; si bien la reforma del 94 a la Constitución Nacional dejó abierta la puerta, cuando en el art. 75, inciso 24, fijó la preeminencia de los tratados vinculados a la integración sobre el resto de la normativa local, con lo cual admitió la cesión de competencia - no se quiso decir soberanía - a los órganos supranacionales - competencias legislativas, jurisdiccionales, administrativas - y la primacía de las normas dictadas por ésos organismos sobre el derecho interno, sujeto, claro está, a que hubiese reciprocidad en los socios.

La lectura del art.40 del Tratado de Ouro Preto es terminante en cuanto a quel el Mercosur no reconoce integralmente los principios de la integración, del derecho de la misma; se prevé la mera publicación de las normas aprobadas y no los efectos de dicha aprobación. "Tampoco tenemos tribunal de justicia permanente, por tanto no puede funcionar este sistema; el Mersocur no es un sistema de integración" ${ }^{46}$

Nada mejor, ni mas elocuente, que observar que sobre el particular disponen las Constituciones Provinciales ${ }^{47}$ :

- la De Santa Fe "contiene una cláusula explícita de reenvío, desde el Derecho Público hacia el Derecho Privado, en materia de responsabilidad del Estado, que no invalida la posibilidad de normar en el futuro sobre el tema dentro de la esfera del Derecho Público infraconstitucional"48 : "En la esfera del Derecho Público la Provincia responde hacia terceros de los actos causados por actos ilícitos de sus funcionarios y empleados en el ejercicio de las actividades que les competen, sin perjuicio de la obligación de reembolso de estos. Tal responsabilidad se rige por las normas del Derecho común, en cuanto fueren aplicables" - art. 18 de la Constitución de la Provincia de Santa Fe de $1962^{49}$.

\footnotetext{
44 Gordillo, ob.cit. p.365.

${ }^{45}$ Barra. ob.cit. p.373 y ss.

${ }^{46}$ Barra, ob.cit.p. 380.

47 Tanto Marienhoff - en su Tratado, 1.I, p. 327 - como Altamira, - P. C. Curso de DerechoAdministrativo, edic. Depalma, Bs. As. 1971, p. 86 y ss. - y Villegas Basavilbaso - B., Derecho Administrativo, edic. T.E.A., Bs.As. 1949, t. I, p. 385 y ss. - se muestran partidarios de la "codificación de las normas sobre responsabilidad del Estado", obviamente en el Derecho Público, como "invalorable contribución a la clarifícación de las cuestiones involucradas en la materia". ${ }^{48}$ Rosatti, H., ob. cit. p. 91.

${ }^{49}$ Lepenies, I., La responsabilidad del Estado y del Funcionario Público en la Provincia de Santa Fe, en Responsabilidad del Estado, ob.colectiva ya citada, p. 495 y ss. La autora, Fiscal de Estado de la Provincia, aclara que respecto de daños originados en actos lícitos se ha tenido muy en cuenta, por los tribunales locales, la enseñanza de Alessi - R., Instituciones de Derecho Administrativo, edic. Bosch, Barcelona 1970 - recogida por Ulla y Rovere, sobre el distingo entre la "Teorla de la Responsabilidad del Estado" y la "Teoría de las Indemnizaciones Públicas". Recuerda que en la Provincia debe traerse necesariamente a juicio a los agentes, ley 7.234 , y que la competencia en tales litigios "es la ordinaria". Frente a manifestaciones de Lorenzetti sobre la extensión del resarcimiento, manifiesta Lepenies que: "una inadecuada ampliación... ("que me causa escalofrío") puede generar la desprotección de quienes no tienen un patrimonio que defender, pero si el elemental derecho a la salud, a la educación, a la vivienda, que frente a la insuficiencia de recursos quedan tantas veces insatisfechos".
} 
- La Provincia de Córdoba consagra la responsabilidad del Estado y de los Funcionarios Públicos en el art. 14 de la Constitución, que ha partir de 1987 expresa: "Todos los funcionarios públicos, aún el Interventor Federal, prestan juramento de cumplir esta Constitución y son solidariamente responsables con el Estado Provincial, por los daños que resulten del mal desempeño de sus funciones. Responden por todos los actos que impliquen la violación de los derechos que se enuncian en la Constitución Nacional y en la presente. A sumir y al dejar sus cargos deben efectuar declaración patrimonial conforme a la ley"s0.

- la Constitución de la Provincia de Mendoza trata de la responsabilidad de los funcionarios, arts. 29, 48 y conds. A estar a un sector de la doctrina mendocina" ${ }^{51}$. "la responsabilidad del Estado debe en principio ser regulada por el derecho local, desde que tambien por principio la actividad de aquel se rige por el Derecho Público". Para otro sector, que integra Kemelmajer de Carlucci - sus votos en el caso "Torres" y en "Díaz de Ghiotti" - la responsabilidad del Estado no es "ni pública ni privada: un derecho de daños con principios comunes, sin perjuicio de especiales particularidades para el daño derivado de la actividad lícita del Estado..." y agrega : "Esta Sala - de la Suprema Corte de Justicia de Mendoza - viene adhiriendo, practicamente sin fisuras, a la tendencia doctrinal que estima que existe un derecho de daños, con principios comunes al derecho público y al privado..." La Corte resolvió que era aplicable el art. 1113 del Cod. Civil, en concordancia con lo dicho por la CS de la Nación, en la causa: "Pose, J.D. c/ Chubut, Provincia de" 52 . Es mui ilustrativo el siguiente párrafo de la jueza Kemelmajer de Carlucci: "La afirmación de que, según las normas del Derecho Público, existe la presunción de que el Estado cumple con las obligaciones determinadas y específicas a su cargo, en mi criterio, está fundado en la exclusiva voluntad de los jueces que la formulan, pues, justamente, insisto una vez mas, cuando se pretende sacar la responsabilidad del Estado de la órbita del Derecho Privado, es para escapar de las dificultades de la prueba de la culpa, para ir a criterios objetivos, o, al menos, de presunción de culpabilidad, que permitan indemnizar a las víctimas por los daños causados con menores dificultades probatorias"53.

- la Constitución de la Provincia de Buenos Aires no contrene normas específicas sobre la responsabilidad del Estado; es por ello que la la C2 CC. de la Plata, sala 3ra., ha podido decidir que: "La responsabilidad extracontractual del Estado por los daños ocasionados por particulares nace de la garantía de la inviolabilidad de la propiedad que establecen los arts. 14 y 17 de la Constitución Nacional y la forma de hacerla efectiva es

\footnotetext{
50 Altamira Gigena, J., Responsabilidad del Estado y del Funcionario en la Provincia de Córdoba, en Responsabilidad del Estado, ob. cit. p. 401 y ss.

5t Sarmiento Garcia, J.H., La responsabilidad del Estado en la Provincia de Mendoza, en Responsabilidad del Estado, ob. cit. p. 381 y ss. Farrando, I. Hh), Responsabilidad del Funcionario en la Provincia de Mendoza, en la ob. cit. p. 479 y ss.

52 Publicada en E.D. 157-85; el fallo es del 1/12/92.

${ }^{53}$ El fallo se encuentra en Voces Jurídicas, 1997, 2, p. 136 y ss. Bercaitz, A., La discrecionalidad administrativa y la arbitrariedad por omisión, en E.D. 137-860.
} 
necesario buscaria en los principios del Derecho común a falta de disposición legal expresa, pues de lo contrario la citada garantía constitucional sería ilusoria" ${ }^{54}$.

- las Constituciones de Misiones, art. 80; Catamarca, arts. 47 y 48; San Juan, art. 43; Salta, art. 5; Jujy, art. 10; La Rosa, art. 48; Chaco, art. 72; Río Negro, art. 55; Formosa, art. 25 y Tierra del Fuego, art. 188, establecen de manera genérica el deber de reparar a cargo del Estado.

- en cuanto a la Constitución de la Ciudad Autónoma de Buenos Aires, la misma no prevé "un régimen normativo general regulatorio de la responsabilidad de los poderes públicos, al estilo del art. 106.2 de la Constitución española o 28 de la italiana. Hay sin embargo, tanto en la Constitución de la ciudad como en algunas leyes, un puñado de disposiciones específicas que contemplan supuestos concretos de responsabilidad pública, tanto en el campo de la actuación lícita, art. 12, inc. 5to., como ilícita, art. 13, inc. 10 y $55^{55}$. Es interesante la afirmación de Sanmartino. Luego de señalar que la jurisprudencia en la Ciudad de Buenos Aires, respecto de causas contra el Estado, no difiere de la dictada en causas contra particulares, agrega: "Y es lógico que sea así pues la justicia civil está estructurada para resolver los conflictos entre particulares y de suyo no puede exigirsele especialización en el Derecho Público. Sin embargo, cabe observar que en muchos casos se advierte que las decisiones no guardaron razonable equilibrio con las posibilidades concretas de gestión, con las dimensiones de la cosa pública local y con el propio sistema económico-financiero en el que está inmersa la ciudad"56.

3.2. No habemos de volver en este tomo sobre la responsabilidad de los Juecez, nacida de sus errores, tema ya considerado en el volumen VII, editado en el año 1999. Solo queremos señalar:

- nuestra coincidencia con el Proyecto de Reforma al Código Civil y Unificación del Derecho Privado, de 1998, en cuanto, en el art. 1677, aplicable los Jueces, dispone: "De los agentes públicos. Alcances. Los agentes públicos tienen responsabilidad directa

\footnotetext{
${ }^{54}$ Remitimos a Medina, G., Responsabilidad del Estado. Provincia de Buenos Aires, en Revista de Derecho de Daños, t.9, ob. cit. p. 425 y ss. Se encuentran receptados en el tomo aludido. fallos de las Provincias de Santa Fe, a cargo de Julia E. Gandolla; Entre Ríos, confeccionado por Pita; Chaco, a cargo de Rinessi, Rio Neglo y Neuquen, tarea cumplida a satisfacción por Varni, M.A. e Iñiguez, M.D.

${ }^{55}$ Sammartino, P.M.E., La responsabilidad de los poderes publicos en la ciudad de Buenos Aires, en Responsabilidad del Estado, ob.cit. p. 503 y ss.

${ }^{50} \mathrm{Si}$ esto se aostiene respecto de la Ciudad de Buenos Aires, cabe preguntarnos qué queda para las Provincias en general y para las denominadas "pobres" en particular. El recorrido por Constituciones provinciales y por la doctrina expuesta al conjuro de las mismas, nos ha permitido receptar el argumento "delos costos" de la responsabilidad por daños y de la necesidad de "bajarlos en consideración a las economías provinciales", argumento que no nos parece aceptable. Así mismo se observan criterios a contramano del derecho común de la responsabilidad, como, por vía de ejemplo, sostener que la caída de un arbol unicado en la vereda es un caso fortuito; o bien que el perjuicio causado con el "arma de la repartición" no compromete al Estado si no ha sido en el "ejercicio" de la tarea encomendada.
} 
por los daños producidos mediante acciones u omisiones que implican el ejercicio irregular de sus cargos. Para requerírsela no son necesatios ni la determinación previa de su responsabilidad administrativa ni, en su caso, su desafuero" ${ }^{\text {; }}$;

- nuestra discrepancia con la norma del mismo Proyecto, art.1686, inc. b): "Casos en los que se exige dolo o culpa grave. Aplicación. Sin perjuicio de disposiciones especiales en los siguientes casos, sólo hay responsabilidad si se obra por dolo o culpa grave: ... c) Si el daño es causado por errores de jueces o de árbitros en el ejercicio de sus funciones" ${ }^{15}$;

- reiteramos, una vez mas, que desde nuestra óptica y comprensión del tema, la acción contra el juez, con base en la invocación de su error, no está - en la normativa vigente - condicionada a la previa remoción de la cosa juzgada; a un "recurso de revisión" - pese a no estar previsto - o a un "juicio previo", destinado a "hacer viable la pretensión". Trámites ambos que, con base en la invocación de la sacralidad de la cosa juzgada, actúan como verdaderos "escudos protectores"

3.3. Tampoco hemos de tratar la muy interesante cuestión - tal vez demasiado avanzada para nuestro desarrollo político - de la responsabilidad de los legisladores, por la sanción de leyes violatorias de la constitución o bien arbitrarias o inicuas ${ }^{60}$. Tema de muy escasas investigaciones en la doctrina autoral. Donde se visualizan las dificultades que posibilidades efectivas ${ }^{61}$.

${ }^{57}$ Es lo que predicamos no solo respecto de jueces, sino de todos los agentes de la Administración Pública. En contra, con base en los textos de las Constituciones de las Provincias, Highton, E.I, La responsabilidad de los jueces en el sistema constitucional argentino. La cuestión del desafuero a los fines de efectivizar esta responsabilidad y la doble inconstitucionalidad del artículo 1677 del Proyecto de Código Civil, en Revista de Derecho de Daños, t. 8., Responsabilidades Profesionales, p. 37 y ss.

58 Mosset Iturraspe, J., Responsables privilegiados: los jueces, en E.D. 186-1169. Al hilo de la ejemplaridad, art. 902, los jueces, como los restantes agentes del Estado, deben "responder de todos los daños causados" y no sólo en los imputables a dolo o culpa grave, asimilada al dolo errores groseros, negligencias mayúsculas.

${ }^{59}$ En contra, manteniendo su opinión favorable a la necesidad de superar como trámite previo la cosa juzgada - "... no es posible calificar como ilegitimo en un juicio civil por responsabilidad contra el juez lo que se ha tenido por valido y legal en otro juicio" -, Kemelmajer de Carlucci, A.R., El deber de 1 os jueces de reparar el daño causado, en Revista de Derecho de Daños, t. 9., Responisabilidad del Estado, p. 93 y ss.

${ }^{60}$ Bianchi, A.B., Responsabilidad del Estado por su actividad legislativa, edic. Abaco, Bs.As. 1999.

6) Si la ley fuere inconstitucional, "esa sola condición le quitaría legitimidad a la función del Estado y abriría sin otro requisito la vía del reclamo en favor del particular dañado". En cambio, "la ley legítima, la ajustada a la Constitución, no abre, en principio y sin más, al eventual damnificado, la acción indemnizatoria". Casiello, J.J. Función legislativa y responsabilidad, en La Responsabilidad, edic. Abeledo-Perrot, Bs.As.1995, p.453 y ss. El tema se complica si pensamos eb la disputa sobre "judicialidad" de las Políticas del Estado; la emergencia y los legisladores que puedan estar comprometidos por sus votos favorables... Cavalieri Filho, S., Programa de Responsabilidade Civil, edic. Malheiros, São Paulo 1999, p. 188 y ss., señala que "la ley, genérica, abstracta e impersonal no puede causar perjuicios"; que pueden ser dañosos, en cambio, "Ios actos jurídicos o administrativos que hagan aplicación de la norma". En el mismo sentido se expide Caio Mário da Silva Pereira, Responsabilidade Civil, 3ra, edic., 9, Forense, p. 335 y ss. 
4.1. Estando de por medio el Estado es siempre oportuno recurrir a León Duguit ${ }^{62}$, cuando afirma que "si la realización de una actividad colectiva, esto es, de una actividad perseverante con el fin colectivo, ocasiona un perjuicio a un grupo o a un individuo, el patrimonio afectado al fin colectivo es el que debe soportar definitivamente la carga del perjuicio".

Ahora bien, en un pais de régimen político federal, como es la Argentina, no puede obviarse el distingo entre la responsabilidad del Estado Nacional, por su Administración; el Estado Provincial, por la suya propia, en los ámbitos de su competencia específica; y el Estado Municipal, por todo aquello que es de su incumbencia.

La doctrina especializada va señalando los criterios para separar lo propio de cada Estado, atendiendo, en primer lugar, a la Constitución Nacional, a lo que aparece "delegado" a la Nación y lo que las Provincias reservaron para sí. Así, por via de ejemplo, se ha entendido, tradicionalmente, que las Provincias han reservado lo atingente a la "regulación de las profesiones liberales" en cambio, siempre como ejemplo, por el art. 41 de la Constitución reformada en 1994, en temas ambientales o ecológicos, "debe existir una ley de presupuestos mínimos del Estado Nacional", una ley ordinaria, en sentido formal-material ${ }^{65}$, mientras se atribuye a las Provincias una competencia propia, "no solo de ejecución, sino la de desarrollo legislativo de la legislación básica y la de imponer medidas adicionales de protección."

De ahí que vayamos a tratar, en capítulos separados, la Responsabilidad del Estado nacional y la de los Estados provinciales. Y tambien por separado la responsabilidad de los municipios o Estados municipales. Hutchinsón dedica un capítulo especial a tratar de las "responsabilidades concurrentes de distintas administraciones" ${ }^{66}$, dentro de las funciones complejas del Estado moderno; y otro a analizar la "concurrencia de una Administración Estatal y de una particular", vale decir, los casos en que la "colaboración" de los privados con el Estado puede originar una responsabilidad conjunta ${ }^{67}$.

4.2. Para Hutchinson, como para la mayoría de los "administrativistas", "en los últimos tiempos se ha avanzado en la elaboración de una teoría propia y sustantiva del Derecho Administrativo, en materia de los conflictos generados por los daños ocasionados por el Estado". Ese "sistema de responsabilidad" responde, para ese autor, a las "características" siguientes:

\footnotetext{
ब2 Duguit, L., Las transformaciones del Derecho Público, 2da. edic., p. 313 y ss.; también su Tratado de Derecho Constitucional, Paris 1927, y su Traité de Droit Administratif, Paris 1930. 63 No obstante ello tanto el Proyecto de 1993 como el de 1998 incluyen normas regulatorias, de las profesiones liberales, que importan, en consecuencia, un avance respecto del criterio tardicional y, por tanto, de ruptura de semejante prejuicio federal.

64 El Proyecto de 1998 de reforma al Código Civil, se ocupa, aunque en minima medida, de los "accidentes de circulación", arts. 1684 y 1685.

${ }_{65}$ Hutchinson, T., en la obra colectíva (con J. Mosset Iturraspe y E.A. Donna) Daño ambiental, t. II, p. 83 y ss., t.I, p. 285 y ss.

66 Afirma Hutchinson que "no es ciencia ficción, entonces pensar que en la práctica se darán hechos o actos jurídicos imputables a dos o mas Administraciones pues la participación y la concurrencia de estas serán comportamientos usuales".

${ }^{67}$ Hutchinson, ob. cit. t.l, p. 316 y ss.
} 
- "dicha responsabilidad alcanza a todas las vertientes de la función administrativa, es decir, todas las actividades - en el sentido general del término: actividad e inactividad - en todas las modalidades; por lo que estan cubiertas por tal sistema, por una parte, la actividad no formal o material (hechos materiales) y la inactividad - omisiones, retardos, abstenciones, etcétera - $y$, por otra parte, la actividad formal, (actos de alcance general y de alcance particular, esto es, actos administrativos) y, desde el punto de vista material, el sistema alcanza a todas las modalidades de actuación (dirección, ejecución, actividad técnica, etc.) "; 68

- "tal sistema de responsabilidad cubre, aunque con distintas modalidades y alcances, tanto a las actividades ilegales o ilícitas, como a las actividades legales o lícitas;"

- "se trata de una responsabilidad directa, pues la Administración responde siempre directamente frente a la víctima, independientemente de las acciones de regreso que la Administración pueda intentar contra sus funcionarios $y$, en algunos casos, contra terceros; ${ }^{69}$

- "tal sistema de responsabilidad es aplicadoes a todas las Administraciones públicas (con las particularidades que pueda tener algún régimen provincial), o, mejor, a todos los Entes Públicos, sean estos territoriales - a nivel nacional, provincial o municipal - o no territoriales - personas de Derecho Público - e igualmente este sistema de responsabilidad alcanza a las personas privadas que actúen en función administrativa;"

\footnotetext{
B8 Para la historia de la responsabilidad del Estado, en nuestro derecho, Diez, M.M., Derecho Administrativo, edic. Plus Ultra, Bs.As. 1971, t. V. Colautti, C.E., Responsabilidad del Estado. Problemas Constitucionales, edic. Rubinzal y Culzoni, Santa Fe, 1995.

69 Un precursor, entre nosotros, de la responsabilidad del Estado fundada en principios de Derecho Público, es Bullrich, R., Responsabilidad del Estado, edic. Menéndez, Bs.As. 1920. Altamira Gigena, J., Responsabilidad del Estado, edic. Astrea, Bs.As, 1973. Reiriz, M.G., Responsabilidad del Estado, edic. Eudeba, Bs.As.1969.

${ }^{70}$ Cassagne - jurista que se ha ocupado con reiteración del tema; Derecho Administrativo, Bs. As. 1986-2.000; En torno al fundamento de la responsabilidad del Estado, en E.D. 99-937; La responsabilidad extracontractual del Estado en la Jurisprudencia de la Corte, en E.D. 114-215 . comienza señalando "la trascendencia" que ha tomado el tema en la jurisprudencia de la Corte. Considera que en "el desarrollo progresivo" de esa evolución se advierte "un marcado predominio de las concepciones imperantes en el Derecho Público, el cual se refleja en tres grandes aspectos básicos: 1. como son el fundamento de la responsabilidad, 2. la naturaleza objetiva del factor de atribución que corresponde aplicar para resarcir los daños provenientes de faltas de servicio producidas por acciones $u$ omisiones de los órganos estatales, $y, 3$. el reconocimiento generalizado de la responsabilidad por los actos ilegítimos o legitimos, en ambos casos en forma directa". Cassagne - glosamos su trabajo: "Las grandes líneas de la evolución de la responsabilidad patriminial del Estado en la Jurisprudencia de la Corte Suprema", en La Responsabilidad del Estado, ob. cit. pp. 29 y ss. - sostiene que "existen diferencias de régimen jurídico", entre la responsabilidad pública y la privada, como la diferencia que resulta del "principio de igualdad ante las cargas públicas", por lo cual, a su juicio, "se resiente la pretendida unidad del fundamento del derecho de daños"; las diferencias, insiste, no son de matices sino sustanciales, "proyectándose a la técnica y a los criterios de aplicación de las formulaciones dogmáticas del Derecho Administrativo". No distingue Cassagne entre "indemnización y responsabilidad" y adhiere, por ende, a una "tesis unitaria sobre el fundamento de la responsabilidad". No coincide con Barra en que "el fundamento de la obligación de indemnizar se encuentra en la justicia legal o general", sino que, entiende, "juegan las tres especies clásicas de justicia": la conmutativa, donde la igualdad se realiza de objeto a objeto; y la distributiva o legal "respecto de la responsabilidad estatal por acto legítimo".
} 
- "es un sistema mixto, no sólo porque él incluye a las actividades lícitas e ilícitas, sino, sobre todo, porque puede dividirse a grandes rasgos en dos regímenes, a los que. podemos resumir en:

1. por una parte, un régimen de responsabilidad por sacrificio particular, en el cual el criterio específico decisivo para la responsabilidad es la imputación a la actividad administrativa de un daño anormal - grave, intenso, especial e individualizado - $y$,

2. por otra parte, un régimen de responsabilidad por funcionamento anormal o por falta, en el cual el criterio específico o decisivo a los fines de la responsabilidad es ese funcionamiento anormal";

- Y concluye Hutchinson: "el criterio general de éste sistema de responsabilidad és, en principio, la idea de "lesión antijurídica", en el sentido de que el particular no tiene la obligación de soportarla sin resarcimiento"71.

Con mucha sensatez, el autor que venimos comentando, Hutchinson, nos dice que la ubicación de la responsabilidad del Estado en el De recho Público o en el Derecho Privado, "responde fundamentalmente al momento histórico en que la situación de analice y a las consecuencias que la adopción de una u otra pueda acarrear"

Es así que la idea que hemos venido reiterando, de una responsabilidad Pública, del Derecho Administrativo, que "acota o limita" la responsabilidad, aparece contradicha cuando se lee, en un sector de la doctrina publicista, que mientras los civilistas continúan predicando la responsabilidad "indirecta o reflaja" del Estado, en el D.A. se alude a otra "directa", que es la consagrada por la CS en el caso "Vadell" de 198473. Que mientrás los civilistas siguien imputando la culpa como factor de atribución al Estado los administrativistas han acordado que esa imputación es objetiva. Son claras al respecto las opiniones de Cassagne y de Hutchinson. Afirma este último: "Parecería que ha llegado el momento de elaborar una teoría única de la responsabilidad del Estado que excluya en su totalidad los criterios subjetivos - pese a la facilidad que los mismos presentanno por ser conceptos de Derecho Privado,- sino por no ser aplicables a los casos de responsabilidad del Estado, sustituyéndolos por una posición objetiva, que apunte basicamente a solucionar la situación de la víctima que ha sufrido un daño. Para esta tarea sobredoa elementos han brindado la doctrina, la jurisprudencia y el Derecho Comparado en general..."74.

4.3 iY qué decir de las pretensiones provinciales en orden a una regulación propia, específica, de la responsabilidad contractual y extracontractual del Estado?

Parecería que desde el Derecho Público se ve con buenos ojos esta posibilidad e incluso de la alimenta o alienta. Otra es la visión desde el Derecho Privado, con base en los

\footnotetext{
7 Hutchinson, ob. cit. p. 399, t. 1.

72 Hutchinson, ob. cit. t. Il, p. 87.

${ }^{73} \mathrm{CS}$, Fallos 306-2.030.

74 Hutchinson, ob. cit. t. II, p. 91 , nota 10.
} 
crite rios, ya recordados, de la "unidad" del Derecho de Daños.

"Las Provincias conservam todo el poder no delegado por ésta Constitución al Gobierno Federal, y el que expresamente se hayan reservado por pactos especiales al tiempo de su incorporación" - art.121 de la CN.

Empero, para los civilistas estas facultades fueron delegadas y se encuentran "dentro del Código Civil". El art. 1112 no es, como pretendem los administrativistas una norma del Derecho Público sino del Derecho Privado. Y, teiteramos, el Estado es "persona jurídica" alcanzada por el art. 43 del CC.

Acontece, como afirma Revidatti, que a la muy intensa influencia ejercida por el Derecho Civil, en los primeros tiempos, sobre la disciplina administrativa, siguió una "reacción" que "fue de desmesura"; y en lugar "de demostrar las diferencias, sin salir de la armonía que refleja en el orden jurídico, se llegó al exceso de pretender no solo la autonomía del Derecho Administrativo dentro del complejo integrado del orden jurídico", sino "de propiciar principios propios y distintos de los que rigen en el resto del Derecho", en particular, agregamos en temas de responsabilidad. ${ }^{75}$

Nos preguntamosiqué ocurriría si, como algunos pretenden, cada Provincia argentina dijera lo que cree conveniente acerca de la reparación de los perjuicios que el propio Estado causa o de los incumplinientos de los actos y contratos celebrados? Sería el caos, sin lugar a hesitación.

Para Perrino ${ }^{76}$ está situación de la falta de regulación orgánica por parte de las Provincias, se debe: a) a un encuadre tradicional, civilista, de la responsabilidad del Estado provincial; $y$, b) "a una falta de toma de conciencia de las Provincias, al no reparar que ellas pueden regular ese tema en tanto integra un cúmulo de facultades no delegadas a la Nación". Para Hutchinsón debe atenderse a que la responsabilidad estatal, "a pesar de ser un régimen de Derecho Público", muestra casos - los mas frecuentes, decimos nosotros - "en que se aplican normas que provienen del Derecho Privado". Y concluye: "Ello porque el deber de reparar del Estado puede originarse, ya sea en una relación do Derecho Administrativo o Público o puede generarse en el campo del Derecho Civil" ${ }^{\prime \prime}$. Y remata con la cita de Mayer ${ }^{78}$ : "Hay situaciones en que el Estado está sometido al Derecho Civil, y lo está cuando actúa en relaciones idénticas a las que se establecen entre particulares, ya que "todo lo que es igual por naturaleza debe ser tambien regulado igualmente".

\footnotetext{
${ }^{75}$ Revidatti, G.A., Derecho Administrativo, edic. F.D.A., Bs.As, 1984.

76 Perrino, P., Jornadas de Derecho Público Provincial y Municipal, p. 73 y ss.

7 Mayer, O., Derecho Administrativo alemán, traduc. por Heredia y Krotoschin, edic. Depalma, Bs.As. 1982, p. 184, t. I.

${ }^{78}$ Hutchinson, ob. cit. t. I, p. 290 y ss. Este jurista recuerda "numerosa normas provinclales", relativas a los daños causados en el marco contractual; los originados en los comportamientos de funcionarios y de las fuerzas de seguridad; y las provenientes de normas locales sobre limitaciones administrativas a la propiedad.
} 
5.1. El Derecho de Daños, desarrollado en el Derecho Privado ${ }^{79}$, apunta a la simplifícación, incluso a la unificación de los ámbitos o "zonas" de la responsabilidad, contractual y extracontractual. La pretensión de construir una "Responsabilidad Pública", a la medida del Estado, lleva inexorablemente a las complicaciones, distinciones, proliferación normativa - provinciales y porqué no municipales, etc.etc. Es impensable, desde el Derezho Administrativo - como veremos en el Capítulo pertinente - una unificación contractual y extracontractual de la responsabilidad del Estado, ${ }^{80}$

Esta "complicación" publicista es, para nosotros, un inconveniente mas de la tesis administrativista, una verdadera contradicción a la luz de la evolución del Derecho de Daños.

Como es contradictorio sostener que la responsabilidad del Estado es eje o el centro del nuevo Derecho Administrativo y, luego, en su exposición "limitar el resarcimiento", abandonar el principio de la reparación integral, para dejar afuera determinados daños patrimoniales, como el "lucro cesante", o extrapatrimoniales, como el daño moral.

De poco sirven principios como el de la "responsabilidad directa" del Estado o el de la "imputación objetiva" si la culminación, que es la sentencia indemnizatoria, se retacea, limita o restringe.

No perdamos de vista que el Estado, aún éste que vivimos, de la "privatización" y la "desregulación" - de la Economía de Mercado y del Neoliberalismo - es un "importante dañador", una persona cuya actuación es fuente de frecuentes y graves perjuicios para los particulares.

Y que el hombre de hoy rechaza todo menoscano o lesión. Y que, en consecuencia, "la preferencia por los gobiernos democraticos no se basa en las propias reglas, sino sobre la esperanza de que esta forma de gobiemo contribuirá al bienestar común e individual y a otros fines deseables. La capacidad de los gobiernos para producir tales fines se considera como un elemento destacado en ${ }^{\circ}$ que hemos llamado aceptación de las reglas legitimadas que, como reglas formales, deben en si legitimarse. El problema de la legitimidad resulta atrapado entonces en la dialéctica de la forma y contenido." ${ }^{81}$

"El Estado solo puede actuar conforme a una vía jurídica, entonces sólo puede desarrollar actividad legitima."

\footnotetext{
79 Una buena defensa de la ubicación de la responsabilidad del Estado dentro del Derecho de Daños, en González Zabala, R.M., El Estado y el derecho de daños, en DJ, 1999-2, p. 807 y ss. ${ }^{80}$ Muchos menos aún cuando, como ocurre para un fuerte sector, se alienta y prohija una "teoría del contrato público" o administrativo, construida sobre "privilegios" o preferencias, cláusulas exorbitantes y derechos discrecionales implicitos.

${ }^{81}$ Claus, Offe, Contradicción del Estado de Bienestar, edic. Alianza, México 1990, p. 123.

82 Hise, M., Rosello, G. Ghersi, C.A., Pronunciamientos de la Corte Suprema de Justicia de la Nación en el resarcimiento de daños, en J.A. 1997-111, p. 1660 y ss,
} 
"El problema central en la reparación de daños por actos del Estado, es la distribución del daño soportable por la comunidad en pos de la convivencia" ${ }^{83}$.

Un sector de la doctrina menciona "el riesgo" como contrapartida de la "reparación del daño individual"; es decir "el riesgo de danosidad" que las personas deben soportar, sin posibilidad ae promover acciones indemnizatorias. Y de alli concluyen que "la fijación del umbral del riesgo y el daño, entre lo individual y social, es determinante, pues ello tiene que ver con el deber de garantia social; es decir, la razón determinante por la cual todo ser humano está dispuesto a ceder parte de su libertad por una medida óptima de seguridad".

Equivale a decir: ¿que daños causados por el Estado deben repararse y cuáles soportarse como precio de la convivencia? ${ }^{74}$

5.2. Cuardo el investigador del tema se adentra en la fundamentación acerca del deber de reparar los daños causados, a cargo del Estado dañador, expuesta por los "administrativistas", observa:

"un afan desmedido y sin razón suficiente por apartarse de la simple fundamentación del deber de indemnizar a cargo de los particulares; que viene desde el Derecho Romano: que ve en el daño la ruptura del equilibrio entre las personas $y$, en su reparación, la vuelta a la justicia ${ }^{85}$;

- un propósito no declarado pero si implícito de hacer de la responsabilidad Público "algo diferente", donde aparezca la "soberanía", los fines del Estado, la justicia distributiva, etc.;

- de alíla prolifereción de "fundamentos", los desacuerdos y en buena medida las afirmaciones contradictórias o encontradas; ${ }^{86}$

- a juicio de los "privatistas" es un debate magnificado, agrandado, en buena medida superfluo; si no fuera por la pretensión, aún mantenida por minorías, de volver a la irresponsabilidad o a la responsabilidad eufemística;

- y si es así en lo que hace a la responsabilidad extracontractual - que es la mas expuesta o desarrollada - ¿qué decir de la "contractual"?.

\footnotetext{
83 Kamerman, S.B., Kahn, A.J., La privatización y el Estado de Bienestar, edic. F.C.E., México 1993 , p. 11.

${ }^{84} \mathrm{La}$ Corte Suprema, en distintos fallos, ha entendido que la función de seguridad se relaciona precisamente con el control del daño y su evitación a los habitantes.

${ }_{85}$ Mosset Iturraspe, J., Responsabilidad por Daños, t. I., Parte General, p. 14.

${ }^{8}$ Es muy interesante el trabajo de Martín Rebollo, L., Los fundamentos de la responsabilidad del Estado, en "Responsabilidad del Estado...", ob. cit. p. 15 y ss. Reconoce allí que "en todo caso, hay una sensación de desbordamiento", en esta cuestión de la fundamentación. Y agrega "una vaga e imprecisa sensación de insatisfacción derivada del casuismo, de los bandazos jurisprudenciales, de las argumentaciones contradictoriàs; de algunos supuestos especialmente significativos, de ciertos excesos tambien, de los cambios en el papel de la Administración y de la inseguridad que todo ello produce". No deja de mencionar elementos "políticos" y de "índole patrimonial", para concluir en que, como afirman algunas sentencias (en España), "todo lo que robustezca el principio de responsabilidad viene a consolidar el prestigio y eficacia de la Administración y la leal colaboración de los administrados".
} 
Sin ánimo de agotar el catálogo, como simple muestra de los criterios sobre "fundamentación", mencionamos:

A) la que se apoya en "principios generales del Derecho" y, muy en especial, en el "Estado de Derecho" y sus postulados, cuya finalidad es proteger el Derecho ${ }^{87}$;

B) la que, sin abandonar los principios, pone el acento de la actividad del Estado en bien de la colectividad entera, y recuerda, en especial, que el Estado es el "asegurador del riesgo social" con base en la "equidad"

C) también desde "los principios" se ha sostenido que la responsabilidad del Estado tiene como fundamento los derechos adquiridos por los particulares ${ }^{89}$;

D) no lejos de estas ideas, pero buscando apoyo en la normativa constitucional, se encuentra el fundamento en los arts. 14 a 20 de la $\mathrm{CN}$, es decir en los derechos individuales que el Estado no puede alterar ${ }^{90}$;

E) como una variante del fundamento constitucional se menciona la imperatividad desprendida de los arts 31 y 116 de la Constitución Nacional ${ }^{91}$;

F) desde otro ángulo, se propicia un fundamento único "consistente en el restablecimiento del equilibrio a fin de mantener la "igualdad" ante los daños causados por el Estado ${ }^{92}$;

${ }^{87}$ Fue expuesta por Marienhoff en su trabajo de 1983: Fundamento actual de la responsabilidad del Estado en el ámbito del Derecho Público. Es compartida en la doctrina nacional por muchas administrativistas, entre ellos mencionamos a Bullrich. Fiorini, Palazzo y otros.

${ }^{88}$ Se atribuye a Duguit, ob. cit. y es compartida en la doctrina nacional por Linares Quintana, S.V., Gobierno y Administración de la Nación Argentina, edic. TEA, Bs.As. 1946, t. II, p. 385. Tambien la doctrina trancesa, siguiendo los lineamientos pretorianos del Consejo de Estado, postu1ó que la base de la responsabilidad del Estado no se halla en un texto positivo de derecho civil, sino en un principio superior de justicia, del cual también proceden los textos que el juez civil debe aplicar. Es pues, se señala, un fundamento de equidad y no de derecho escrito. Waline, M., Droit Administratif, Paris 1963.

${ }^{39}$ Se atribuye a Gierke. En el derecho aleman se sostiene que la responsabilidad del Estado se origina en la inviolabilidad de los derechos adquiridos y en la garantía constitucional de la propiedad privada. De Estrada, J.R., Responsabilidad del Estado por actos legislativos y discrecionales, en ED. 102-843.

${ }^{90}$ Gordillo, A., La responsabilidad extracontractual del Estado por hechos y actos de la Administración Pública, Bs.As. 1959 y su Tratado varias veces recordado.

Cassagne, J.C. ob. cit. t. I, p. 276 y ss. Este jurista distingue entre el deber de "soportar el sacrifício" y el de "sufrir el daño". Garrido Falla, F., Tratado, edic. Centro de Estudios Constitucionales, Madrid 1985, V. II, Cap. IV, p. 245 y ss., el "fundamento teórico de la indemnización reside en la igualdad de los ciudadanos ante las cargas públicas, lo que hace odioso el sacrificio especial sin indemnización. Este autor se enrola entre los que distinguen "indemnización" y supuestos de "responsabilidad".

${ }_{31}$ Reiriz, Responsabilidad del Estado, ob. cit., p. 42 y ss.

${ }^{92}$ Cassagne, J.C. ob. cit. t. I, p. 276 y ss. Este jurista distingue entre el deber de "soportar el sacrifício" y el de "sufrir el daño". Garrido Falla, F., Tratado, edic. Centro de Estudios Constitucionales, Madrid 1985, V. II, Cap. IV, p. 245 y ss., el "fundamento teórico de la indemnización reside en la igualdad de los ciudadanos ante las cargas públicas, lo que hace odioso el sacrificio especial sin indemnización. Este autor se enrola entre los que distinguen "indemnización" y supuestos de "responsabilidad". 
G) no puede omitirse, por la trascendencia adquirida en la dctrina nacional, la teoría denominada del "sacrifício especial", atribuida a Mayer, en la doctrinn alemana y que funda la responsabilidad en la existencia de un perjuicio desigual y desproporcionado en cabeza de un individuo, respecto de los demás integrantes del grupo social. Se recurre a ella en especial criando se trata de la responsabilidad por actos lícitos o de la derivada de actos normativos; ${ }^{93}$

H) no queremos dejar de lado la invocación, como fundamento, de la "justicia distributiva", como una justicia diferente de la conmutativa; apta para resolver desde el Estado cuestiones que tienen que ver no solo con el Derecho sino con la Política y con las Finanzas ${ }^{94}$;

I) la teoría "de la expropiación", atribuida al jurista italiano Consolo, ha tenido en nuestro país muy importantes adherentes, que han visto el argumento por analogía para "limitar" la cuantía del resarcimiento, los rubros aceptados ${ }^{95}$.

Para concluir, y en homenaje a la regla o principio implícito de lógica jurídica ${ }^{96}$, recordemos las palabras de García de Enterría, que traducen su asombro ante estas "preocupaciones acuciantes". Dice el Maestro español:

"... puede parecer ocioso insistir sobre la necesidad de establecer un sistema de responsabilidad civil de la Administración. Desde el punto de vista jurídico, como eremos, lo que sería preciso justificar es la solución contraria; es decir, el principio de una inmunidad de la Administración respecto a la responsabilidad derívada de daños causados por su actuación; ésta justificación se ha venido proponiendo secularmente en virtud de principios cuya consistencia dogmática se ha derrumbado estrepitosamente, y no es posibibe ya encontrar un solo argumento objetivo que abone el postulado de la irresponsabilidad... La doctrina parece haber llegado en nuestros días a la tesis común de que la razón que justifica una responsabilidad de la Administración no es, ni tendría razón alguna para

ss Para Bianchi, A.B., Responsabilidad del Estado por su actividad legislativa, ob. cit. p. 136, la generalidad de la doctrina nacional, con la importante disidencia de Marienhoff, ha adherido a este fundamento.

${ }^{94}$ Barra, R.C., Responsabilidad del Estado por revocación unilateral de sus actos y contratos, en E.D.122-859.

${ }^{95}$ No nos parece una analogía afortunada o feliz. La expropiación reconoce causa en la utilidad pública, en el bien común, mientras la reparación de un daño injustamente sufrido es ajena a aquella justificación. Es verdad que tanto en la expropiación como en el daño se le quita a alguien lo suyo, un bien de su propiedad, como es la salud, o la integridad del patrimonio o el buen estado de ánimo. Pero no puade dejarse de lado el actuar ilegítimo de quien daña a otro, - la injusticia del perjuicio sufrido por un inocente. La teoría de la expropiación, en síntesis, recurre como fundamento de la responsabilidad del Estado al Derecho de Propiedad. Pero llega a resultados diferentes cuando, atendiendo a las razones para expropiar, concluye en una indemnización limitada o recortada.

${ }^{96}$ Así denomina a este criterio de propio Marienhoff, al hacer la exposición de los diferentes fundamentos invocados por la doctrina. En su Tratado, 6ta. edic. $n^{0} 1629$, p. 721. 
hacerlo, distinta de la que justifica la posibilidad de aplicar la misma instrucción a las personas privadas..." ${ }^{\prime 9}$.

5.3. Resabios, solo resabios de un Estado "fuerte", preocupado por mostrar su "imperio", celoso de su soberanía, mas por "distribuir" a su manera que por la relación conmutativa, son las razones para mantener una responsabilidad contractual con características tan singulares que la apartam y diferencian de la propia del "derecho común" o derecho civil. Una relación mas vertical que horizontal, mas hecha de discrecionalidad que de acuerdos.

Es como si la cuestión de los contratos, de su fuerza imperativa, del juego de la autonomía de la voluntad, y, por ende, de la revisión, resolución o extinción, fuera tambien un tema del Derecho Administrativo, librado a la regulación de las Provincias.

El ciudadano común puede preguntarse, validamente, porqué el Estado, que en muchas circunstancias asume la posición de parte fuerte, en relación dominante, no "aprovecha" para "contratar por la adhesión" a cláusulas predispuestas por el mismo; porque no incorpora, dentro de la admisible o lícito, aquellas estipulaciones que hacen a su interés y protegen su situación. Quál es la razón para "reservarse" facultades, para insistir en su derecho a lo excepcional o exorbitante; cuál para pretender actuar con discrecionalidad rayana en el capricho.

No solo está de por medio el Estado de Derecho, sino tambien la "seguridad jurídica", el "respeto a la palabra empeñada", la regla "pacta sum servanda, de abolengo romano, y el deber de no frustrar las razonables expectativas del coccntratante..$^{98}$

\footnotetext{
${ }_{97}$ Garcia de Enterría, E., Los principio de la nueva ley de expropiación forzosa, edic. Civitas, Madrid 1984, p. 159 y ss. Con razón afirma Mairal - Responsabilidad del Estado en el Derecho Comparado, en Responsabilidad del Estado, ob. cit. p. 367 y ss.: "...de nada sirve tener un sistema de responsabilidad del Estado muy generoso en teoría si después el monto de la sentencia es muy reducido". Coincidimos plenamente.

${ }^{98}$ Bustamante, J.E., El contrato Administrativo, en Contratos Administrativos, obra colectiva, ob. cit. p. 215 y ss. Menciona Bustamante que "la solución entonces, para limitar el riesgo de explotación, transita por reducir al mínimo el ámbito de discrecionalidad. Es fundamental que los contratos administrativos introduzcan elementos de certidumbre respecto de ambos contratantes y que existan mecanismos objetivos de resolución de conflictos. En términos técnicos requieren seguridad jurídica... la teoría general del contrato administrativo confiere al Estado facultades exorbitantes implícitas, conforme a las cuales el Estado puede variar las condiciones pactadas (Jus variandi), puede exigir el cumplimiento aún cuando el Estado no pague (inoponibilidad de la exceptio non adimpleti contractus); puede obligar al contratista a seguir sus órdenes para la ejecución del contrato y puede rescindir el contrato en forma anticipada (resdate), por motivos de oportunidad o conveniencia. La existencia de estas ciáusulas exorbitantes implícitas claramente atentan contra la seguridad jurídica, elevando los costos de transacción. Estos costos, en definitiva, son transferidos al Estado por vía del precio cotizado o por la disminución de la calidad del bien o del servicio contratado".
} 
Recordemos un vez mas a Mairal"9: "Nosotros hemos abusado de la teoría del contrato administrativo como abusamos de la emisión monetaria. Sin emisión, el país se ha vuelto masserio y mas confiable. Sin teoría del contrato administrativo tambien el país sería mas serio y mas confiable." 100

Y cerramos aquí este capitulo introductorio, no sin antes confesar las escasas referencias al Derecho Comparado ${ }^{101}$, que intentaremos suplir en cada uno de los capítulos que se ocupan de supuestos especiales de responsabilidad del Estado. ${ }^{102}$

${ }^{9}$ Mairal, $\mathrm{H}$., La teoría del contrato Administrativo. Una visión diferente, partidaria a la figura cuestionada, en Cassagne, J.C., En torno a la categoría del contrato administrativo (Una polêmica actuaf). En el mismo sentido favorable, el trabajo de Sarmiento García, J.H. "E1 iur variandi y los contratos de la Administración. Todos en Contratos Administrativos, ob. cit., obra colectiva, ps. 209, 17 y 221 y ss., respectivamente.

100 Coviello, P.J.J., E1 contrato administrativo en la jurisprudencia de la Corte Suprema de Justicia de la Nación., ob. cit. e, nota precedente, p. 83 y ss.

${ }^{101}$ Mairal, H.A., Responsabilidad del Estado en el Derecho Comparado, en Responsabilidad del Estado, ob. cit. p. 367 y ss,; una interesante visión del tema en los derechos lialiano, francés y español, en la obra de Leguina Villa, J., La responsabilidad civil de la Administración Pública, edic. Tecnos, Madrid 1983. Sobre la responsabilidad extracontractual de la Comunidad Europea, la obra de Muñoz Machado, S., La responsabilidad civil concurrente de las Administraciones Públicas, edic. Civitas, Madrid 1992.

${ }^{102}$ Como afirma Mairal en la mayoría de los países * que transitan similar estadio de evolución * "existen reglas especiales", sobre la Responsabilidad del Estado, algunas provenientes del Derecho Privado y otras del Derecho Público ob. cit. p. 371. También para el Derecho español, la obra de González Pérez, J., Responsabilidad Patrimonial de las Administraciones Públicas, 2da. edic. edit. Civitas, Madrid 2.000, obra muy completa, que incluye la "responsabilidad derivada de actos legislativos" y la emergente de los Tratados Internacionales. Para el Derecho italiano, Pilato, S., La responsabilitá amministrativa. Profili sostanziali e processuali nelle leggi 19/94, 20/94 e 639/96, edic. Cedam, Padova 1999. Dentamaro, M., YI. Danno ingiusto nel diritto pubblico, edic.Giuffre, Milano 1996. 